\title{
Why are professional library meetings so bad?
}

\author{
By Jonathan D. Lauer \\ Library Director \\ Houghton College
}

Last April I passed an important milestone in my library career, having reached my tenth anniversary as an academic librarian. A decade is not a lifetime, nor is it a career, but ten years does constitute a measure of time most would consider significant. Through those years I have attended scores of library meetings; local, regional, and national. They have included committee meetings, hands-on workshops, vendor presentations, panel discussions, business meetings, and continuing education classes. I am sorry to say, with a few notable exceptions, these meetings have been amazingly bad. As I was yawning and fuming through a plenary session at a regional workshop recently, I gathered a few notes which I hope shed some light on this problem, one we sorely need to address. On to my prolegomena.

1) Speakers at library meetings are anything but dynamic. Even our big guns, our nationallyknown luminaries, more often than not drone on interminably. When not droning, they mumble, demonstrating the meaning of inarticulate in its most basic sense. College juniors in required public speaking classes are more compelling. Perhaps most appalling is that speakers commence without having been introduced, or short of that, even introducing themselves. Either we are expected to know them or they assume we do not care who they are. In most cases, neither of those assumptions is correct.

2) Participants are insensitive to the purpose of varying types of meetings, particularly plenary sessions of workshops and conferences. In the nitpicky atmosphere we seem to love to foster, questions and comments inappropriate in a large group setting are endured by scores while two participants engage in dialogue they should be having over coffee, or in a small group setting.

3) Vendors sell and users gripe. Our lack of professionalism in dealing with each other is embarrassing. Meetings billed as workshops to update skills become trade shows hawking new products. On the other hand, librarians know no shame when given the opportunity to tell vendors their products are next to worthless for not laundering clothes and shining shoes.

4) Facilities are too often ill-suited to the gathering. Lecture halls with a capacity of 500 are booked for a meeting attracting 80 participants. Classrooms designed for 25 are packed to the gills with
42 librarians anticipating a "small group discussion." Acoustics are poor, sound equipment substandard, lighting is bad, and temperature controls haywire. We melt. We freeze.

So we have a lot to learn about meetings and public speaking. Fortunately, many of us can draw on local resources. Most colleges and universities have personnel in charge of hosting special campus events, conferences, Elderhostels, and the like. Their expertise and experience can be of great value. And apropos of public speaking, try the communications department and the media center (seen yourself on video lately? It can be a frightening, but highly instructive experience). Or perhaps we need to call a conference on holding professional meetings. Most anything would help.

\section{Grants for humanities projects}

The National Endowment of the Humanities has invited applications for projects in its Division of Research Programs' Access category that will increase the availability of important research collections in all fields of the humanities. Priority will be given to projects that provide access to materials that are national in scope or impact. Support is provided for archival arrangement and description projects, bibliographies (including bibliographic databases), records surveys, cataloging of print, graphic, film, sound and artifact collections, indexes, foreign microfilming, other guides to humanities documentation, and projects to improve the ways repositories make research documentation available. The Endowment particularly encourages proposals for the compilation of comprehensive guides to the bibliographic and archival resources of whole fields or subjects in the humanities.

Awards usually range from $\$ 10,000$ to $\$ 150,000$ depending on the scope and magnitude of the project.

For application materials and further information, write or call: Access, Room 318, Division of Research Programs, National Endowment for the Humanities, Washington, DC 20506; (202) 786-0358. Deadlines are November 1, 1988, and September 1, 1989. 
THE ACQUISITIONS LIBRARIAN

14 COMMUNITY \& JUNIOR

COLLEGE LIBRARIES

This refereed journal is the funda-

This new journal offers librarians and information professionals a unique service-each issue is devoted to a single broad but well-defined and practical issue of immediate concern to everyone working in library/information center acquisitions and collection development.

$\square$ AUSTRALIAN \&

NEW ZEALAND JOURNAL OF

SERIALS LIBRARIANSHIP

This forthcoming journal-a counterpart to the British Journa of Serials Librarianship-will be devoted to the concerns of serials librarians in Australia, New

Zealand, and the South Pacific area, with special contributions of international significance.

$\square$ BEHAVIORAL \& SOCIAL SCIENCE LIBRARIAN

This unique journal presents the latest research by leading librarians in the dynamic field of social and behavioral sciences.

1 BRITISH JOURNAL OF SERIALS LIBRARIANSHIP This new quarterly journal will be devoted to serials librarianship practice and research in Great Britain, featuring developments of international importance.

\section{CATALOGING \&}

CLASSIFICATION QUARTERLY

This valuable journal provides a wealth of material on the bibliographic control and the practica constructs of cataloging and classification systems.

\section{COLLECTION}

\section{MANAGEMENT}

This practical journal focuses on all aspects of collection management and development that affect college, university, and research libraries of all types. mental resource for all community and junior college librarians.

JOURNAL OF BUSINESS \& FINANCE LIBRARIANSHIP This new quarterly journal will be devoted entirely to providing useful articles to information professionals who are involved with, or have an interest in, the creation, organization, dissemination, retrieval, and use of business information.

\section{JOURNAL OF LIBRARY} ADMINISTRATION

A primary source of information on all aspects of library administration, this valuable journal emphasizes the application of theory to everyday problems faced by library administrators.

\section{LEGAL REFERENCE}

SERVICES QUARTERLY

A working tool for people who are involved in contact with legal research materials, this highly regarded journal is especially directed toward the working reference librarian.

\section{LIBRARY \&}

ARCHIVAL SECURITY

This highly praised journal provides vital information to librarians, scholars, and researchers concerned with security planning, policies, procedures, and strategies for both libraries and archives.

MEDICAL REFERENCE SERVICES QUARTERLY A "working tool" for medical and health sciences librarians of all types, this helpful jouriıal specializes in practice-oriented articles relating to medical reference services, with an emphasis on online search services.
PUBLIC LIBRARY

QUARTERLY

This stimulating journal addresses the major administrative challenges and opportunities that face the nation's public libraries.

\section{$\square$ THE REFERENCE}

LIBRARIAN

Each issue of this acclaimed thematic journal focuses on a particular topic that is of current concern, interest, or practical value to the practicing reference librarian.

\section{RESOURCE SHARING \& INFORMATION} NETWORKS

A major force in the field of library networking, this valuable journal provides a forum for ideas on the basic theoretical and practical problems faced by planners, practitioners, and users of network services.

\section{SCIENCE \& TECHNOLOGY}

LIBRARIES

This insightful journal-at the forefront of the information explosion-provides a wealth of instructive material prepared specifically for the science and technology librarian.

THE SERIALS LIBRARIAN This essential journal-devoted exclusively to serials management for librarians-provides pertinent articles to help all serials professionals.

\section{SPECIAL COLLECTIONS}

This high quality journal presents a thorough and skillful description and current analysis of library collections in the arts, sciences, social sciences, and humanities.

\section{TECHNICAL SERVICES}

\section{QUARTERLY}

This readable journal, devoted to new trends in computer automation and advanced technologies in the technical operation of libraries and information centers, features articles by the most highly regarded professionals in the field.

\section{ORDER FORM}

The Haworth Press, Inc., will be pleased to send you free samples of our periodicals that are relevant to your library's interests and needs, but we do ask that you be selective. To request samples, check the journals which you would like to examine more closely and complete this form.

CRLN AD88

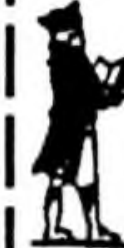

Please photocopy this page and return to

THE HAWORTH PRESS, INC. 12 West 32nd Street

New York, New York 10001-3813
NAME

LIBRARY

INSTITUTION

ADDRESS

CITY

STATE

ZIP

SPECIAL INTERESTS 


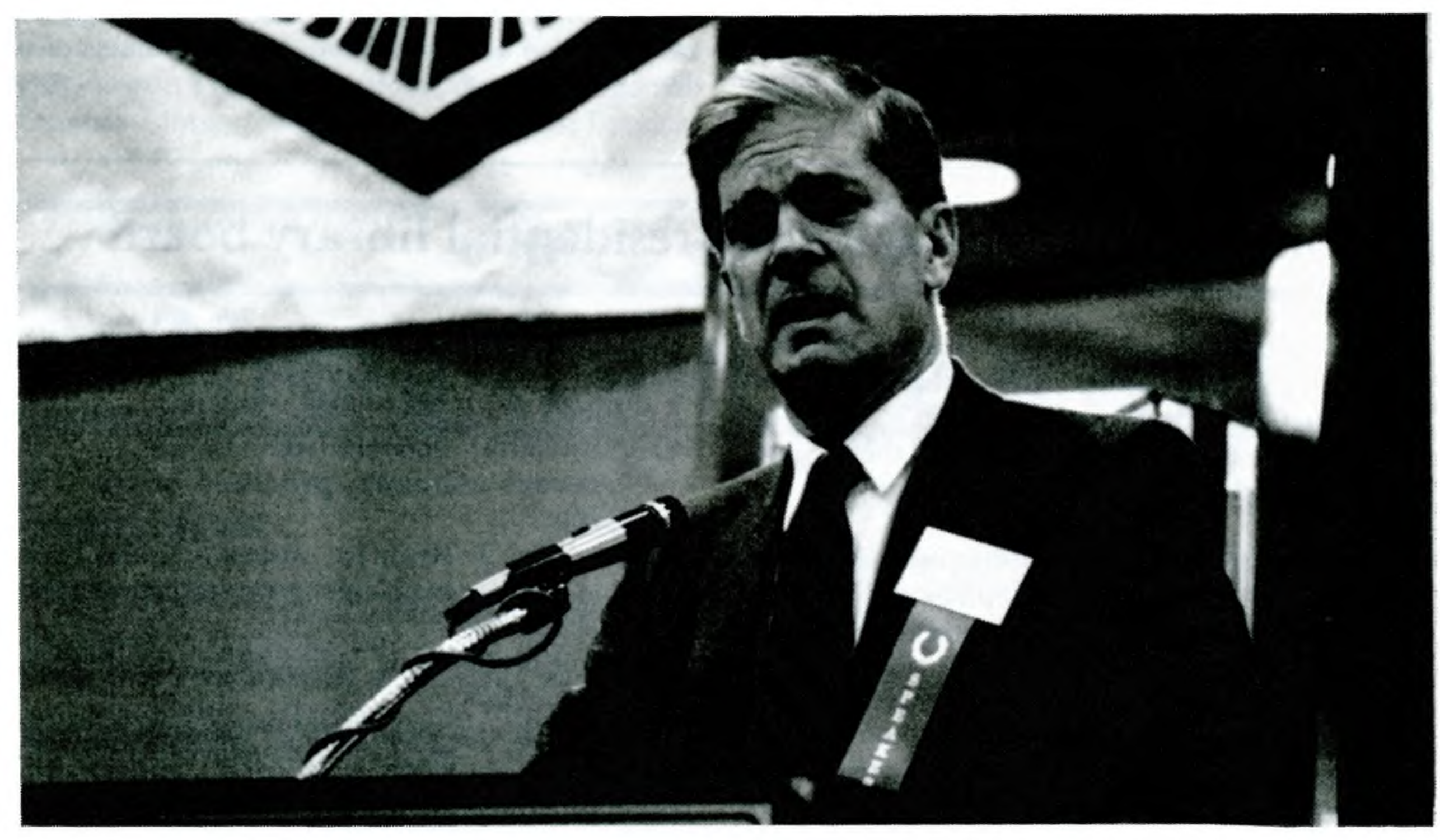

James H. Billington, Librarian of Congress.

\section{Midwest regional conference}

Around 450 academic librarians from Iowa, Minnesota, North Dakota, South Dakota, and Wisconsin together met for the first time in La Crosse, Wisconsin, on April 27-29. The conference was sponsored in part by a grant from ACRL and featured 50 different programs of interest to public and technical services librarians from small and large academic libraries.

Keynote speakers were James $\mathrm{H}$. Billington, Librarian of Congress; Joanne Euster, ACRL's President; and Charles Bailey, who presented the speech that was to be delivered by President Van Horn of the University of Houston. The three-day conference also included a one-day CAI workshop led by Patricia Arnott and Deborah Richards from the University of Delaware, as well as a one-day CD-ROM Fair.
Other highly rated sessions included two presentations by Judy Myers, University of Houston, on 1) loss of access to information in the government sector, and 2) expert systems; and a presentation by James Sweetland, University of WisconsinMilwaukee, on the impact of laser disk technology on reference service. Other programs included peer presentations that provided opportunities for librarians from the five states to share their own ideas, research, and practical experience with their colleagues.

Plans will be made for another regional conference within the next five years to promote the cooperation and information sharing begun this year.Lois Komai, Steenbock Memorial Library, University of Wisconsin, Madison.

\section{ARL's confidentiality statement}

In the wake of current actions by the FBI and other government agencies that inhibit the freedom of individuals to receive and exchange ideas, the Association of Research Libraries (ARL) adopted a Statement on Library Users' Right to Confidentiality at their 112th membership meeting in May. The complete text of the statement follows:

"The Association of Research Libraries is committed to the principle that unrestricted access to and dissemination of ideas are fundamental to a democratic society. Libraries, in addition to their other information services, exercise a unique responsibility in preserving the freedom of citizens to receive and exchange ideas. Public confidence in libraries must not be shaken by any breach in the confidentiality of individual use of library resources.

"The Association condemns the efforts of any government agency to violate the privacy of library users, to subvert library patron records, and to intimidate or recruit library staff to monitor so-called 
'suspicious' library patrons or report on what or how any individual uses library resources. Such actions are an affront to First Amendment free- doms, individual privacy, and all citizens' right to know. These actions violate the basic tenets of a democratic society."

\section{National Archives establishes Presidential library board}

The Archivist of the United States, Don W. Wilson, announced today the establishment of an Advisory Committee on Presidential Libraries. The eight Presidential libraries around the U.S. are operated and maintained by the National Archives.

The committee will be a standing advisory group with no fixed duration; each member will serve renewable three-year terms. The committee will be composed of nine members initially, each providing a perspective on the development of Presidential libraries. The members are:

- Martin J. Allen Jr., banking executive and chairman of the board of the Gerald R. Ford Foundation.

- David Eisenhower, grandson of the former President and author of the recent Eisenhower at War.

- George M. Elsey, president emeritus of the American Red Cross.

-William J. vanden Heuvel, president of the Franklin and Eleanor Roosevelt Institute in New York City.
- Tom Johnson, publisher and chief executive officer of the Los Angeles Times.

- Robert J. Lipshutz, who served as counsel to President Carter, and now practices law.

- Jeremiah Milbank, president of the J.M. Foundation.

- Frederick J. Ryan Jr., assistant to the President and director of private sector initiatives at the White House.

- Caroline Kennedy Schlossberg, daughter of the late President.

Wilson said the committee is "essential to the effectiveness of the libraries' archival, museum, and public programs by ensuring that they are responsive to public needs and interests." He called the nine members "a singularly distinguished group who will provide fresh insights on how the libraries can enhance their roles as research centers and community resources."

The committee will hold its first meeting in Washington, D.C., in the fall of 1988. The Presidential libraries are: Herbert Hoover Library, West Branch, Iowa; Franklin D. Roosevelt Li-

\section{LOOKING FOR A JOB?}

ACRL's Fast Job Listing Service brings you job notices four weeks before they appear in College \& Research Libraries News. This monthly bulletin also contains job postings that, because of narrow application deadlines, do not appear in $C \& R L$ News.

The Fast Job Listing Service is sent to subscribers by first-class mail the first week of every month. You can be a step ahead of other job applicants by seeing position descriptions very shortly after they are received in our office.

Subscriptions to the Fast Job Listing Service are for a period of six months-by that time we hope you have found the job you're looking for! The cost is $\$ 10$ for ACRL members and $\$ 15$ for non-members.

You may use the form below to enter your subscription.

YES! I want to see job notices as quickly as possible by subscribing to ACRL's Fast Job Listing Service.

I am a member of ACRL and am enclosing $\$ 10$.

I am not a member of ACRL and am enclosing \$15.

NAME:

ADDRESS:

\section{CITY/STATE/ZIP:}

Please make checks payable to ACRL/ALA and send to the Fast Job Listing Service, ACRL/ALA, 50 E. Huron Street, Chicago, IL 60611. 
brary, Hyde Park, New York; Harry S. Truman Library, Independence, Missouri; Dwight D. Eisenhower Library, Abilene, Kansas; John F. Kennedy Library, Boston, Massachusetts; Lyndon
B. Johnson Library, Austin, Texas; Gerald R. Ford Library, Ann Arbor, Michigan; Jimmy Carter Library, Atlanta, Georgia.

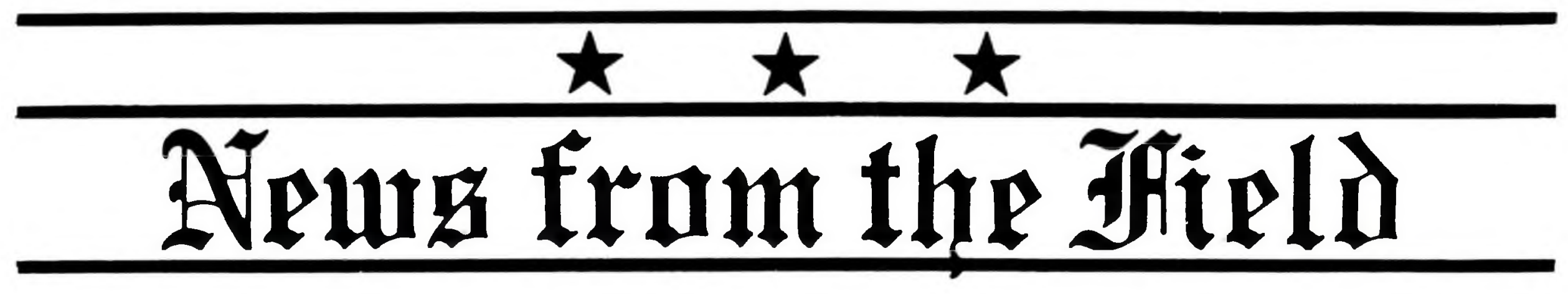

\section{Acquisitions}

- Earlham College, Richmond, Indiana, has been given a collection of 1,100 genealogical works, primarily relating to Quakers, by Willard and Virginia Heiss of Indianapolis. Willard Heiss is a noted genealogical consultant and author on Quaker genealogy. In addition to published works, the collection includes many typed and manuscript genealogies, diaries and family histories, as well as copies of census data, county histories, and several genealogical serials.

- Johns Hopkins University, Baltimore, Maryland, has received the papers of Abel Wolman, a Hopkins professor for more than 50 years and an internationally known activist on behalf of safe public water supplies. Wolman is known as a codeveloper of the control procedures for chlorination of water and sewage, now used throughout the world. A 1913 Hopkins graduate, he is now 96 and holds the title of professor emeritus of sanitary engineering and water resources. The collection of some 55 cubic feet, with more expected, includes speeches, publications, reports, and committee papers, and traces Wolman's career as a teacher, consulting engineer and adviser to local, national and international agencies. Included are materials from his long tenure at Hopkins during which he taught courses on sanitary engineering and international health planning. A great deal of material relating to the Potomac River dates from Wolman's work as consulting engineer for the Washington Suburban Sanitary Commission, an agency he helped launch.

- North Carolina State University, Raleigh, has received a collection of more than 1,500 mystery novels from Jack Levine, professor emeritus of mathematics and an expert in cryptography. Most of the books date from the "Golden Age" from 1920 to 1940 , and many are hardcover editions in original dust jackets.

-The St. Louis Mercantile Library's John W. Barriger III National Railroad Library, Missouri, has acquired a number of long runs of rare 19th and early 20 th century railroad periodicals. Comprising some 10,000 individual issues, the journal runs were acquired at auction in March as part of the sale of the holdings of Philadelphia's Franklin Institute. Of note is the acquisition of a long though incomplete run, from the first issue in 1832 through 1973, of the American Railroad Journal and its various successor titles, including Railway Mechanical Engineer and Railway Locomotives and Cars. The publication is considered the earliest American railroad trade journal. Also acquired was a substantial though incomplete run of ARJ's British counterpart, Herapath's Railway and Commercial Journal, from 1835-1890, and a number of predecessor titles. Other railroad journals include regional titles from the latter half of the 19th century, considered the heyday of railroad construction in the United States. The Mercantile Library also acquired an 1880-1915 run of Miller's Gazette and Corn Trade Journal, a British publication of interest to researchers exploring the worldwide agricultural markets of the period, and two American imprints, The Modern Miller and St. Louis Miller. Three late 19th century runs of metals industry journals and other railroad and agricultural journal runs were also purchased.

- The University of California, Los Angeles, has received an important collection of television historical materials from Terrence O'Flaherty, TV critic for the San Francisco Chronicle for 37 years. The collection includes some 300 document boxes of promotional material spanning virtually the entire history of American television, from its infancy in 1949 through 1986, when O'Flaherty resigned from the Chronicle. Included are 60,000 still photographs, 2,500 press kits, 125 network kits, 198 posters, 516 books, 154 long-playing recordings, and 72 promotional 45 RPM recordings. The 12,000 television reviews O'Flaherty wrote during his career and his extensive correspondence with top industry personnel will also eventually become part of the collection. Nearly every major American television program or series broadcast during 1949-1986 is represented in some form, including "Adam-12," "Bonanza," "Dragnet" and "The Ed Sullivan Show." All the best-known actors, actresses, news commentators, musical performers, politicians and sports figures of American Television history are likewise represented. The collection is part of the Theater Arts Library and will be 